\title{
Aviation/Aerospace Teacher Education Workshops: \\ Program Development and Implementation
}

\author{
Mavis F. Green
}

University of Illinois

\begin{abstract}
This paper addresses development of an Aviation/Aerospace Teacher Education Workshop. This of workshop, targeted toward elementary school teachers to encourage the promotion of aviation to their students, has been successfully offered nationwide. This paper addresses practical issues dealing with program development including program intent, benefit to the sponsoring institution, program model, credibility, co-sponsorship and potential problems. Establishing an effective advisory committee and considerations when performing formative and summative evaluations are also discussed.
\end{abstract}

\section{Program Intent}

\section{Program Development}

Aviation/Aerospace Teacher Education Workshops are important to both the aviation and education communities. These workshops have been recommended by the Illinois Task Force for Aviation/Space Education (1988) as a way of encouraging aeronautical education. The Task Force was sponsored by the Illinois State Board of Education and the Illinois Department of Transportation - Division of Aeronautics and was comprised of a blue ribbon task force of professionals in both fields. The task force endorsed two initial premises:

"Great technological challenges are being met by a dynamic aerospace industry that requires the intellect and dedication of motivated young people and an understanding public. Aerospace touches the lives of every citizen, yet the awareness of career opportunities, the economic impact, the beneficial spin-offs are little understood by the average citizen" (p. ii).

and that

"The need for widespread aviation/space education in our schools and the public arena has never been more evident than today" (p.ii).

The need is not only specifically for aviation education, but for science education in general. Newspaper and popular magazine articles constantly bemoan the test scores of U.S. students in the sciences when compared with other countries. According to Strickler (in Illinois Task Force for Aviation/Space Education, 1988), trained educators see aerospace 
education as basic education $_{2}$ and use aerospace as a motivating and meaningful medium through which to teach the basic academic subjects. They take advantage of the interests that students have in aviation and space to teach such basic subjects as geography, English, mathematics, science, physical education, arts, business, etc.

The aviation community also has a great need to diversify -- to encourage the participation of women and minorities. Currently, only $6 \%$ of all FAA certificated pilots are women. Early exposure to the potential opportunities in the field may help encourage future participation by this segment of society.

If there are so many advantages to aviation/space education, why is it not taught more in the schools? According to Marcec (in Illinois Task Force for Aviation/Space Education, 1988), the regular classroom teacher looks at aviation/space as another technical science area in which they do not know the terminology and do not understand the concepts.

Familiarizing teachers with the topic, and especially how it can be correlated with non-science subjects, may increase their participation.

\section{Sponsorship}

A college or university is a logical sponsor of this workshop. Many institutes of higher learning have a threefold mandate which includes teaching, research, and service. These workshops would certainly help meet the public service requirement. Boyle (1981, p. 65) states that "Educational institutions should be responsible for facilitating the use of knowledge to serve the public."

Sponsorship of these workshops may also help an institution maintain support throughout its state for its other programs by showing that it is interested in promoting the general welfare of the state. An institutions willingness and eagerness to help implement this recommended course in the furtherance of improved elementary education by providing sponsorship and making its facilities available, may also help win political support in a time of budgetary constraints.

\section{Program Model}

There are a number of ways to discuss the model of program development suitable for this workshop. According to Boyle (1981), a model of program development is used as a rationale for selecting procedures. His "Institutional" classification seems to apply to the type of program being proposed: "Many professionals, such as teachers... are required to earn a certain number of units per year to update their knowledge in their field. They enroll in courses or workshops designed to develop or improve their understanding of new information and research as well as techniques" (p. 11).The objectives, which are developed from the knowledge within the discipline are, according to Boyle (p. 11), often part of a "larger problem-solving effort." In this case the problems which need to be addressed include 
increasing cultural diversity in technically-oriented fields, improving science skills in U.S. students, and updating teacher competence and competitiveness.

The viewpoint to be used will have elements of the naturalistic as elucidated by Houle. Planning decisions will be made using practical contexts of action through a deliberative process in a specific context. Included, but not limiting, will be ideas from the "Classical" viewpoint of program development proposed by Tyler. The four questions posed by Tyler, including what result the program plans to obtain, through what type of educational experiences these results will be obtained, through what type of organization and how evaluation for achievement will occur are all essential to a program. However, many other questions must also be answered.

The situation must be properly analyzed, and the educational design chosen on this basis. Elements of Knowles and Donaldson seem especially important for consideration in development of this program. Knowles emphasizes participant involvement and utilization of experience. Teacher education must take into account the reality of the environment the teacher operates in and the individual teachers expertise in this area. Failure to do so will definitely result in alienating this population. Respect for the experiences of the teachers is essential to the success of the program. Their participation in developing curricula ideas from the knowledge provided them, as a goal of the workshop, is also essential to its success.

Communication and relationship building, as espoused by Donaldson (1990), is also extremely important. The power to influence teachers and to gain continuing support for the program, and for aviation in general, rests with the ability to build confidence in the sponsors' expertise and ability to understand the educator's workplace.

\section{Potential Difficulties}

Among the difficulties which might be encountered, gaining teacher participation looms paramount. Much of the incentive for teachers to enroll in the workshop must come from their ability to achieve continuing education units that can be used to either proceed toward an advanced degree or as a basis for fulfilling mandatory continuing education requirements leading to an increase in salary. Educational institutions need to provide innovative ways for teachers to meet these mandatory requirements (Boyle p.67). These credits must be offered to participating educators. The program will have potential economic benefit to the teachers if, as a result of obtaining credits, they receive a raise.

Weekend and summer workshops have also become less attractive to teachers as salary constraints make it difficult to receive pay for participation. Ideally, a grant can be obtained to pay the teachers full cost of enrollment, and provide a stipend for participation. A National Aeronautics and Space Administration grant that stipulates a portion of the money be used to promote and support these Aviation/Aerospace Teacher Education Workshops is a potential source of funding. 
An additional obstacle to the participation of the teachers might be their fear of being "burdened" with additional material they must now shoehorn into an already overcrowded schedule. It must be emphasized to them, through marketing of the program, that the purpose of the workshop is to show how easily aviation topics and examples can be incorporated across their current curricula to enhance education.

\section{Program Implementation}

\section{Advice and Support}

There are many levels of support and advice that will be needed in ensuring an effective program. Caffarella (1988) talks about the need for support on the local, regional, state and community levels. Working within a university environment, this partially translates to support from within the sponsoring college. School systems within the host state, national sponsors and the trainees themselves must also be consulted. Munson (quoted in Caffarella 1988) states that within these areas, support must come form three major groups: top management, the immediate supervisors of potential training participants, and the trainees themselves.

Internal support. Within the aviation department of the sponsoring institution, active involvement should be sought from the director, assistant director, head of pilot training, and the chief pilot. At a minimum, their support must be rendered in the form of authorizing release time from normal duties for workshop organization. Optimally, however, their active involvement will allow utilization of their expertise for advice on implementation and scheduling. Their participation in events, possibly acting as instructors or resource persons, and assisting with the awarding of certificates at the end of the program, will also add greatly to the credibility of the program.

It is essential that teachers receive graduate or continuing education credits for attending the workshop. The appropriate colleges within the university should be consulted for advice on obtaining this credit for teachers. Faculty contacts willing to sponsor the program and participate are essential. Any requirements for classroom hours, curriculum content or instructor qualifications must be planned for in advance to insure against last minute surprises. Participants must be notified in advance of any paperwork they will need to have completed or credentials ready for presentation at the workshop.

External support. School principals and science program coordinators also need to be recruited for support of the program. Accepting the program as valid and offering in-house certification credit, where appropriate, will encourage attendance by their teachers. Their advice on developing curriculum ideas that will conform to any applicable state educational goals can also be helpful. 
The support and advice of the trainees themselves is vital to the continuing success of the program. Any teachers currently using aviation materials in their class can be used as instructors or resource persons for a portion of the workshop. The success of future programs will depend on good word-of-mouth recommendations.

National aviation organizations and government agencies may also provide advice and information on resources available for the teachers to access.

Advisory committee. Program credibility can be offered through the establishment of an advisory committee with members from both the internal and external support groups. Caffarella (1988) says that subject experts, process experts, organizational leaders, and consumers are types of people needed on an advisory committee (see Table 1.) While an advisory committee is needed for program development, one is also needed for implementation. These two committees may be composed of the same, different, or additional members. It is essential, however, that the prime committee representative act as a stimulator (Apps p.83) to "sell" the program to the other advisors and co-sponsors. The other committee roles he lists must also be filled - analyst, facilitator, and encourager. An appropriately staffed advisory committee can add a great deal of prestige and credibility to a program, making participation desirable.

Expert knowledge on the committee must be provided in at least two domains: aviation subject matter, and presentation of material to elementary school children. Aviation experts can be provided from within the aviation department. The teachers, however, will be most concerned in how this material can be effectively used in their classrooms. An expert in elementary educational practice needs to be included in the planning process.

The process expert will be the program planner, but may include others with similar functions within the institution. The program planner must be able to establish linkages between the diverse groups involved in the program, and establish comfortable working relationships based on mutual trust. The less pleasant role, as suggested by Dahl, might be one of "administrator", ensuring all work is performed on schedule. The planner must also act the role of entrepreneur. While ideally, the costs of the program will be covered by grant money, the full variety of support needed to make the program viable must be actively solicited.

Organizational leaders that need to be consulted for advice include the National Aeronautics and Space Administration, the Federal Aviation Administration, the Civil Air Patrol, and the state D.O.T./Division of Aviation. The Aircraft Owners and Pilots Association and General Aviation Manufacturers Association may also be useful in supplying advice on program implementation. These organizations may be interested in sending speakers to participate in a portion of the workshop. Their participation would also lend additional credibility to the program. 
Last, but absolutely not least, is participation by the consumer - -again emphasizing the importance of including an elementary school teacher on the advisory committee.

Teachers will be enrolling not simply for aviation knowledge, but for ideas on how they can use this knowledge in their classroom. It is essential that an elementary school teacher be included in the program planning advisory committee. That teacher should be involved in every aspect of program planning and activity development to insure that the program remains relevant to the concerns of the teachers. The teacher should also be involved with program implementation to provide insight into elementary training needs. Boyle (1981) feels that having client representation will speed up the process of change and reduce resistance to the program (p. 95). He also feels that those who are involved will aid in diffusing information about and legitimizing future programs. The advice supplied by this individual can help insure that the program is addressing needs and supplying information of use and interest to the participants.

\section{Program Objectives}

Houle states that "Any learning activity is...a force field in which many other purposes than the professed goals are in operation,..." An explicit objective may be that professed goal - the intended result of a specific training activity (Caffarella 1988). The "other purposes" may be thought of as implicit objectives. It is important for the program planner to be aware of both explicit and implicit objectives in order to design learning activities that will orchestrate between them and enable them to be met. There are three major categories of learning outcomes: Knowledge acquisition, skill building and attitude change. Educational objectives, focusing on the learners, are based on these possible outcomes and are composed of three components: performance, conditions, and criterion (Caffarella 1988).

\section{Table 1}

Recommended Program Planning Advisory Committee Membership
Type
Example

Caffarella(1988)

Subject Experts

Process Experts

Organizational Leaders

Education

Consumer Representatives
Aviation Education Specialist

Elementary Education Specialist

Administrator/Analyst/Facilitator

Governmental Representatives: FAA, CAP, NASA

Industry Representatives: AOPA, GAMA

Education Representatives: Dept. or Board of

Elementary School Teacher 
Explicit objectives. The explicit objectives of the workshop fall primarily in the knowledge and skill building domains. At the outcome of this workshop the participants will be able to explain aviation fundamentals. They will be able to recognize the applicability of aerospace education across the curriculum and be able to prepare lesson plans that incorporate aviation themes. The participants will also be able to describe issues facing aviation today.

Implicit objectives. The implicit objectives for the workshop seem to fall primarily into the attitude domain. One objective is for the participants to become advocates for aviation in general. The participants will accept and recognize aviation as a motivating and meaningful medium through which to teach basic academic subjects as well as technical material. They should endorse the use of aviation across their curriculum and select to use lesson plans incorporating aviation themes. A final implicit objective is to build good will toward the sponsoring institute.

\section{Learning Activities}

A variety of instructional techniques should be used to obtain the explicit and implicit objectives. This workshop will provide continuing professional education to elementary school teachers, and must address preferred learning styles. Adults in general, according to Knowles, prefer a problem- based orientation. Teachers in particular want hands-on experiential learning experiences that have immediate and practical application in their classroom. A combination of lecture, guest lectures, simulations, video, demonstrations and hands-on projects, case studies, group projects, written assignments and field trips will be used during the week-long course of the workshop.

A knowledge base does have to be developed during each unit of instruction. This will be accomplished primarily through lectures, group projects and demonstrations. It is extremely important that each lecture present not only subject content, but suggestions for and examples of integration into a primary curriculum. Skill building will occur through case studies, hands-on projects, and written assignments. Attitude changes will occur through the interaction of all the designated learning activities.(Caffarella 1988)

\section{$\underline{\text { Program Evaluation }}$}

It will be important to evaluate this program in a number of different ways. The overall value of the program and its ability to meet the stated objectives must be evaluated to determine if the program should be continued as is, modified, or discontinued. It is also important to evaluate each unit of instruction for effectiveness and relevance for the participants.

There is a danger in overevaluating, especially in terms of participant dissatisfaction. In terms of formative evaluation, two short evaluation cards could be provided to the teachers each day. One card could be at the classroom desks in the morning and collected as 
participants leave for lunch. The second card could be completed at the end of the afternoon. Evaluation of specific program activities will be less reliable the farther removed in time from the actual learning experience, and so should be done immediately following the session to be evaluated. The formative evaluation process may help foster a feeling of collaboration among the workshop participants. Also, changes in the format of following lessons can be made in a timely manner, if needed, to help ensure the success of the program.

Questions can be posed on a Likert-type scale, allowing participants to agree or disagree along a continuum. Space should be included, however, for general comments from the participants. At times, items that have not been considered for evaluation get brought to the forefront in this manner. Teacher responses should not be unduly restricted.

Summative evaluation to determine to what extent course objectives have been met can occur through a questionnaire mailed to participants six months after course completion. This form can solicit information on how the teachers are using aviation in their classes, as well as their overall impression of the usefulness of the program to them and their students.

\section{Comments}

An Aviation /Aerospace Teacher Education Workshop has the potential to be a first rate program that will benefit both the sponsors and attendees. The relationship that will be established between the sponsoring institution and the participating teachers will be important to both. These teachers can help maintain a steady flow of students into the institutions aviation programs. The teacher/participants will be able to make contacts with teachers of similar interests through the program and will have the time to forge strong relationships. The good feelings the participants will leave with will hopefully translate into positive action in support of aviation .

The big winners, however, will be the students. As the students become educated about aviation in their classes they may not elect to fly or pursue aviation as a career. They will at least, however, be able to analyze issues dealing with aviation more knowledgeably. Hopefully, they will support aviation in a time when the industry appears to be under fire. They will undoubtedly have teachers who are better able to prepare them for the technological challenges they will encounter in the century to come.

\section{References}

Apps, J. (1979). Problems in Continuing Education. New York: McGraw-Hill. Bennett, N. \& LeGrand, B. (1990). Developing Continuing Professional Education

Programs. Urbana-Champaign: The Board of Trustees of the University of Illinois.

Boyle, P. (1981). Planning Better Programs. New York: McGraw-Hill.

Caffarella, R.S. (1988). Program Developmaent and Evaluation Resource Book for Trainers.

New York: John Wiley \& Sons. 
Donaldson, J. (1990). Managing Credit Programs in Higher Continuing Education. UrbanaChampaign: The Board of Trustees of the University of Illinois.

Cervaro, R.M. \& Wilson, A.L. (1991, May-June). Perspectives on program planning in adult education. Proceedings of the Adult Education Research Annual Conference, 32, 39-48.

Houle, C. (1972). The Design of Education. San Francisco: Josey-Bass.

Illinois Task Force on Aviation/Space Education. (1988). Report. Springfield, IL: State Board of Education and DOT - Division of Aeronautics.

Knowles,M. (1980). The Modern Practice of Adult Education: from Pedagogy to Androgogy. New York: Cambridge.

Lauffer, A. (1978). Doing Continuing Education and Staff Development. New York: McGraw-Hill Book Company.

Tyler, R.W. (1970). Basic Principles of Curriculum and Instruction. Chicago: University of Chicago Press. 